\title{
Differential Levels of Fertilizer and Row Spacing Affects Growth and Yield of Brown Top Millet [Brachiaria ramosa (L.)] in Entisols of Bastar Plateau Zone of Chhattisgarh
}

\author{
Danish Ahmed Siddiqui, G.K. Sharma*, T. Chandrakar, A.K. Thakur and A. Pradhan
}

\author{
Shaheed Gundadhur College of Agriculture and Research Station, Kumhrawand, \\ Jagdalpur-494005, Chhattisgarh (India)
}

*Corresponding author

\section{Keywords \\ Brown top millet, Row spacing, Fertilizer doses, Entisols}

\section{Article Info}

Accepted: 26 July 2020 Available Online: 10 August 2020

\section{A B S T R A C T}

A field study was conducted at S.G. College of Agriculture and Research Station, Jagdalpur (Chhattisgarh). The experiment was laid out in a split plot design with 3 levels of fertilizer as main plot and 4 levels of row spacing as sub plot with 3 replications. Results showed that the highest values of fingers plant ${ }^{-1}(9.9)$, finger length $(16.3 \mathrm{~cm})$, leaves plant ${ }^{-1}(11.5)$, leaf length $(18.1 \mathrm{~cm})$, leaf area index (1.36), grains finger ${ }^{-1}(519)$, biological yield (53.3 q ha $\left.{ }^{-1}\right)$, grain yield $\left(6.4 \mathrm{q} \mathrm{ha}^{-1}\right)$ and straw yield $\left(46.9 \mathrm{q} \mathrm{ha}^{-1}\right)$ were recorded under $125 \%$ of RDF. These parameters increased significantly with the increase in level of fertilizer from 75 to 100 and 100 to $125 \%$ of RDF. The plant height and harvest index were recorded significantly higher under $125 \%$ of RDF than $100 \%$ RDF but 100 and $75 \%$ of RDF was at par with each other. The tillers plant ${ }^{-1}$ and leaf width under $125 \%$ of RDF were significantly higher than $75 \%$ of RDF but at par with $100 \%$ RDF. The test weight under $125 \%$ of RDF was at par with $100 \%$ RDF and significantly higher than $75 \%$ RDF. The highest values of plant height $(106.9 \mathrm{~cm})$, leaf area index $(1.49)$, biological yield $\left(68.3 \mathrm{q} \mathrm{ha}^{-1}\right)$, grain yield $\left(7.4 \mathrm{q} \mathrm{ha}^{-1}\right)$ and straw yield $\left(60.9 \mathrm{q} \mathrm{ha}^{-1}\right)$ were recorded under 22.5 $\mathrm{cm}$ row spacing and these parameters increased significantly with narrowing the row spacing from 60 to 45,45 to 30 and 30 to $22.5 \mathrm{~cm}$ except plant height where 60 and $45 \mathrm{~cm}$ spacing were at par. The highest values of tillers plant ${ }^{-1}(6.0)$, secondary tillers plant ${ }^{-1}(7.0)$, fingers plant ${ }^{-1}(11.2)$, finger length $(15.9 \mathrm{~cm})$, leaves plant ${ }^{-1}(11.4)$, leaf width $(2.2 \mathrm{~cm})$, leaf length $(17.5 \mathrm{~cm})$ and grains finger ${ }^{-1}(485)$ were recorded under $60 \mathrm{~cm}$ of row spacing and these parameters decreased significantly with narrowing the row spacing from 60 to 45,45 to 30 and 30 to $22.5 \mathrm{~cm}$ except secondary tillers where 22.5 and $30 \mathrm{~cm}$ was at par, leaves plant $^{-1}$ where 30 and $45 \mathrm{~cm}$ was at par and leaf width where 22.5 and $30 \mathrm{~cm}$ and 45 and $60 \mathrm{~cm}$ were at par. The leaf area index responded significantly to higher doses of fertilizer i.e. 100 and $125 \%$ of RDF at each level of row spacing. The leaf area index didn't respond to lower level of fertilizer i.e. $75 \%$ of RDF under wider row spacing i.e. $60 \mathrm{~cm}$. Narrowing the row spacing from 45 to 30 or $22.5 \mathrm{~cm}$, responded significantly to each and all the levels of fertilizer under study. 


\section{Introduction}

Every day, we make choices about the food we eat and our lifestyles. We can make choices for ourselves and our families that make a real difference to our ability to remain healthy and active now and enjoy life to its fullest in the future. Over past few years, the people are becoming conscious about the food habits and there is a lot of demand for nutritive food and people are switching to millets which are rich in nutrients. Millets are cereals with highly variable small-seeded grasses, which can be cultivated in the dry or degraded soils. The nutritive value is rich in millets that own 378.1 calories of energy, 11 $\mathrm{g}$ of protein, $8 \mathrm{mg}$ of calcium, $195 \mathrm{mg}$ of potassium, $3 \mathrm{mg}$ of iron and $4.3 \mathrm{~g}$ of fat per $100 \mathrm{~g}$ (USDA, National Nutrient Database, 2015). These millets are serving to overcome malnutrition among rural poor, and one among such millet is this Brown top millet. It can be a source to overcome malnutrition.

Browntop millet (Brachiaria ramosa L.) belongs to the family Poaceae (Grass family) and is called with different names at different places like locally called as pedda-sama and korne, Korale in Kannada and Andakorra in Telugu (Fuller, 2014). It can be considered as both annual and perennial warm-season grass (Sheahan, 2014). It's an introduced annual grass originated from South East Asia. It's cultivated in Arabia, China, Australia and India (Clayton, 2006). Recently this crop is gaining popularity in several dry parts of India in terms of cultivation and consumption. It's a major staple crop of Deccan (Fuller et $a l ., 2004)$. In India, though the crop gaining lots of importance because of its nutritional value; its cultivation and the distribution is very low and is restricted to Andra Pradesh, Karnataka, and Tamil Nadu states of South India (Kimata et al., 2000). The brown top millets are also rich in many nutrients and are very delicious. The millet is free from gluten and rich in essential nutrients. Also, it's rich in fiber $(12.5 \%)$ compared to other crops. Lower incidence of cardiovascular diseases, duodenal ulcer, and hyperglycemia (diabetes), reported among those who regularly consume millets.

Nutrient supply in soil is one of the most important factors that determine the growth of the crop. Fertilizer is the major source of plant nutrients required in sufficient quantity to maintain the nutrient supply in the soil. The response of crop to fertilizers varies widely from place to place, depending upon the native fertility level of soil, environmental condition and genotype. A crop would express its full potential only when it is backed up by good agronomic practices. Optimum plant density provides conditions for proper light interception throughout the crop growth period. Further, it is important to realize that plant density should be defined not only in terms of number of plants per unit area but also in terms of arrangement of these plants on the ground (planting geometry/spatial arrangement) as it helps in efficient harvesting of solar energy with least competition for growth factors viz., water and nutrient uptake which ultimately decides the expression of phenotypic and genotypic character of the crop.

Chhattisgarh has four different soil types i.e. Entisols, Inceptisols, Alfisols, and Vertisols mainly developed by the action and interaction of relief, parent material, and climatic factors. Entisols cover $19.5 \%$ cultivated area of the state, most of the Bastar plateau contains these soils are known for absence or near absence of horizons that reflects the soil formation process. Though, the Entisols aren't thought well for the production of many crops, millets can be grown successfully. The soil is very hard and harsh which leads to limited root and shoot growth. With proper water supply and 
fertilization, these soils can be used in agriculture (USDA-NRCS, 2006). Many attempts have been made to utilize the land for the millets still the information on agronomic practices, nutrient doses and their management are lacking.

Browntop millet, suitable for cultivation in Entisols, is very rich in nutrient value and can be utilized for eradication of malnutrition in the near future. Henceforth, an attempt has been made to undertake this study with the objective to calibrate optimum level of fertilizer with optimum plant population for yield maximization of brown top millet.

\section{Materials and Methods}

\section{Location and physiographic setting}

The experiment was carried out during Kharif 2019 at Upland Research cum Instructional Farm, Shaheed Gundadhur College of Agriculture and Research Station, Lamker, Jagdalpur, Bastar (Chhattisgarh).

Bastar plateau agro-climatic zone lies between the latitude ranging from 17044' to 20030' North and longitude from 82015' to 82020' East and, physiographically, is a part of Dandyakaranya upland, which is characterized by undulating topography with well marked elevations and depression with complex and heterogeneous setting (S. R. Ratre, 2014).

\section{Climate and weather conditions}

The climate of the zone is hot and sub humid with hot summer and cool winter. The zone receives an annual rainfall of 1300 to 1600 $\mathrm{mm}$ mostly in the month of July and August. The zone is flats in some parts while most of it undulating with slopes of varying magnitude (S. R. Ratre, 2014).

\section{Soil type}

In Bastar, the land is undulating and hence the soils vary considerably from top of the hillock to the valley. The soil types in Bastar district vary from Marhan (Entisols) to Gabhar (Vertisols). Gabhar is the valley portion of the undulating terrain. Tikra (Inceptisols) and Mal (Alfisols) lies in between these two (S. R. Ratre, 2014). Most of the Bastar plateau contains these Entisols. Though, the Entisols aren't good for the production of many crops, millets were grown better. It may form in a variety of climatic conditions. The soil is very hard and harsh which leads to limited root and shoot growth. With proper water supply and fertilization, these soils can be used in agriculture (USDA-NRCS, 2006).

\section{Cropping history of the experimental field}

Sometimes, the experimental results may get affected by the previous crop grown and the experiment carried out over there in that particular area. Henceforth, knowing the cropping history may help in solving many technical errors. The crops being taken during last 3 years were maize during kharif season of 2016 and 2017 and brown top millet during kharif season of 2018.

\section{Experimental details}

The field experiment was framed with a total of 12 treatment combination of the application of 3 differential levels of fertilizer with 4 differential levels of row spacing of brown top millet (variety wild) in a split plot design with 3 replications and its impact on crop yield was assessed after harvesting of crop. The fertilizer levels were composed of 75,100 and $125 \%$ of recommended dose of fertilizer (RDF) which was 40:20:00 kg nitrogen: phosphorous: potassium $\mathrm{ha}^{-1}$. The row spacing of brown top millet tested under study was $22.5,30,45$ and $60 \mathrm{~cm}$. In the 
present experiment two split doses of nitrogen was applied, initial dose of $50 \%$ was applied during the time of sowing and the rest was applied 15 days after sowing.

\section{Crop management}

The plot was ploughed well using tractor drawn disc plough; cultivator was used to break the clods and to loosen the soil before taking the experiment. The layouts were made concerning different treatments and replications. The seeds which were locally available were hand sown in the experimental plot on 27 July 2019. Weeds may be the major obstacles in the present experiment. Henceforth, three hand weeding was carried out to suppress there activity. The plant protection measures were taken as per the need of the crop. Once when the fingers were matured the crop was harvested manually.

\section{Observations recorded}

\section{Initial soil analysis}

Initial soil samples were collected and analyzed for estimation of $\mathrm{pH}, \mathrm{EC}, \mathrm{OC}$ and available $\mathrm{N}, \mathrm{P}, \mathrm{K}, \mathrm{Mn}, \mathrm{Zn}, \mathrm{Fe}$ and $\mathrm{Cu}$ using standard procedures and the data are presented in table 1 . The $\mathrm{pH}$ was recorded using $\mathrm{pH}$ meter. The electrical conductivity of soil was estimated using EC meter. The organic $\mathrm{C}$ in soil was estimated using Walkley and Black titration method (1939). The $\mathrm{N}$ was determined by alkaline potassium permanganate method of Subbiah and Asija, 1956. Soil available phosphorus was extracted by $\mathrm{NaHCO}_{3}(\mathrm{pH} 8.5)$ as described by Olsen et al., (1954) and P in extract was determined by ascorbic acid method using spectrophotometer (Watnabe and Olsen, 1965). The soil potassium was extracted by neutral normal ammonium acetate and determined with the help of flame photometer as described by Muhr et al., (1965). The available micronutrients $\mathrm{Zn}, \mathrm{Cu}, \mathrm{Fe}$ and $\mathrm{Mn}$ were extracted by using $0.005 \mathrm{M}$ diethylene triamine penta acetic acid, $0.01 \mathrm{M}$ calcium chloride dehydrate and $0.1 \mathrm{M}$ amine buffered at pH 7.3 (Lindsay and Norvell, 1978) and content were analyzed using atomic absorption spectrophotometer (AAS).

\section{Growth and yield attributes}

The plant height $(\mathrm{cm})$, number of grains finger $^{-1}$, finger length $(\mathrm{cm})$, number of finger plant $^{-1}$, number of branches plant ${ }^{-1}$, number of productive tiller plant ${ }^{-1}$, number of leaves plant $^{-1}$, leaf length $(\mathrm{cm})$, leaf width $(\mathrm{cm})$, leaf area index, grain yield $\left(\mathrm{q} \mathrm{ha}{ }^{-1}\right)$, straw yield ( $\mathrm{q}$ $\left.\mathrm{ha}^{-1}\right)$, biological yield $\left(\mathrm{q} \mathrm{ha} \mathrm{h}^{-1}\right)$, harvest index (\%) and test weight (weight of 1000 grains) were recorded using standard procedure.

\section{Results and Discussion}

The variations in the yield and growth parameters of brown top millet due to levels of fertilizer and row spacing are presented in table 2 and figure 1-15 and the results are interpreted and discussed with the supportive reasons here under following heads.

\section{Plant height}

The highest plant height $(103.3 \mathrm{~cm})$ was recorded with the application of $125 \%$ of recommended dose of fertilizer which was significantly higher than 100 and $75 \%$ of recommended dose of fertilizer. The plant height under 100 and $75 \%$ of recommended dose of fertilizer was found at par with each other. Similar findings were also reported by many workers (Prakash and Singh, 2014; Prakasha et al., 2018).

The highest plant height $(106.9 \mathrm{~cm})$ was recorded with the row spacing of $22.5 \mathrm{~cm}$ which was significantly higher than the row spacing of 30,45 and $60 \mathrm{~cm}$. It was found that 
plant height of brown top millet significantly increased with narrowing the row space from 45 to 30 and 30 to $22.5 \mathrm{~cm}$. A possible reason for increased plant height upon narrowing the row spacing is that the more number of plants per unit area increased both the photosynthesizing area and the volume of roots per unit soil surface, allowing the crop to improve the exploitation of environmental resources. Lower light interception, might be due to less inter-plant competition for light at wider row spacing, could have reduced assimilate production (Amjad and Anderson, 2006). Optimum planting density varies with climatic conditions, soil type, location, sowing time and varieties (Hulihalli and Shantveerayya, 2018).

\section{Number of tillers plant ${ }^{-1}$}

The highest number of tillers (5.4) of brown top millet was found under $125 \%$ recommended doses of fertilizer which was on par with $100 \%$ recommended dose of fertilizer and significantly higher than $75 \%$ recommended dose of fertilizer. Similar findings were reported by Kumari et al., (2015), however, Obeng et al., (2012) didn't get response of fertilizer levels in number of tillers.

The highest number of tillers per plant (6.0) of brown top millet was found under row spacing of $60 \mathrm{~cm}$ which was significantly higher than row spacing of 45, 30 and 22.5 $\mathrm{cm}$. It was found that number of tillers per plant of brown top millet significantly decreased with narrowing the row space from 60 to 45,45 to 30 and 30 to $22.5 \mathrm{~cm}$. Kumari et al., (2015) was also observed similarly.

\section{Number of secondary tillers plant ${ }^{-1}$}

The highest number of secondary tillers plant

${ }^{1}$ (5.3) of brown top millet was found when $125 \%$ recommended dose of fertilizer was applied which was at par with 100 and $75 \%$ of recommended doses of fertilizer. The results were in accordance with Kashik and Gautham (1991); Pandey et al., (1988); Yadav and Jangir (1997) and Hulihalli and Shantveerayya (2018).

The row spacing of $60 \mathrm{~cm}$ was recorded the highest number of secondary tillers plant $^{-1}$ (7.0) which was significantly higher than the row spacing of 45,30 and $22.5 \mathrm{~cm}$. It was found that number of secondary tillers plant ${ }^{-1}$ of brown top millet significantly decreased with narrowing the row space from 60 to 45 and 45 to $30 \mathrm{~cm}$. The results were in accordance with Ka; Pandey et al., (1988); Yadav and Jangir (1997) and Hulihalli and Shantveerayya (2018).

\section{Number of fingers plant ${ }^{-1}$}

Application of $125 \%$ recommended dose of fertilizer recorded the highest number of fingers (9.9) per plant which was significantly higher than 75 and $100 \%$ of recommended doses of fertilizer. Number of fingers per plant increased significantly with each successive level of fertilizer doses. The results were in accordance with findings of Nigade and More (2013) that the higher doses of fertilizer applied to the crop resulted in an increase in no. of fingers in plant.

Row spacing of $60 \mathrm{~cm}$ recorded the highest number of fingers (11.2) per plant of brown top millet. Number of fingers per plant of brown top millet increased significantly with each successive level of row spacing. The results were in accordance with Dereje et al., (2016), who reported significantly highest number of fingers of finger millet under 40 $\mathrm{cm}$ of row spacing. Similarly, Mahato and Adhikari (2017) reported maximum no. of tillers per plant with the row spacing of 20 $\mathrm{cm}$. 


\section{Finger length}

The result reveals that the application of 125 percent recommended dose of fertilizer recorded the highest mean finger length (16.3 $\mathrm{cm}$ ) of brown top millet. The mean finger length of brown top millet was increased significantly with each successive level of fertilizer. The present results were in accordance with the results obtained by Choudhary et al., (2002) who reported the higher finger length of pearl millet, when 60 $\mathrm{kg}$ per hectare of nitrogen was applied to the crop. Similarly Nigade and More (2013) reported the increase in finger length with proper doses of NPK applied to the crop. Contrary to this, Giana (2014) reported that the fertility levels did not bring significant variation in ear length of pearl millet.

The result reveals that the row spacing of 60 $\mathrm{cm}$ recorded the highest mean finger length $(15.9 \mathrm{~cm})$ of brown top millet. The mean finger length of brown top millet increased significantly with each successive level of row spacing. Similarly, Sonboir et al., (2017) reported the higher length of panicle was observed in paddy with the row spacing of 20 $\mathrm{cm}$ which was in accordance with the results obtained in the present study.

\section{Number of Leaves plant ${ }^{-1}$}

The result reveals that the application of 125 $\%$ recommended dose of fertilizer in brown top millet produced the highest number of leaves (11.5) per plant. The number of leaves per plant of brown top millet increased significantly with each successive level of fertilizer.

The data reveals that the row spacing of 60 $\mathrm{cm}$ produced the highest number of leaves (11.4) per plant of brown top millet. Significantly higher number of leaves of brown top millet was recorded with each successive level of row spacing except row spacing of 30 and $45 \mathrm{~cm}$ which was at par with each other. The findings were in accordance with Chamroy et al., (2015), who reported the highest number of leaves per plant of 13.6 with the wider spacing in maize. Also, Dona et al., (2017) reported higher number of leaves per plant of maize when planted with the row spacing of $60 \mathrm{~cm}$.

\section{Leaf width}

The data reveals that the highest leaf width $(2.3 \mathrm{~cm})$ was registered with $125 \%$ recommended dose of fertilizer which was significantly higher than $75 \%$ of recommended doses of fertilizer and statistically at par with $100 \%$ of recommended doses of fertilizer. Korir (2019) also reported that the leaf width differs significantly with doses of fertilizer.

The data reveals that the highest leaf width $(2.2 \mathrm{~cm})$ of brown top millet was registered with row spacing of $60 \mathrm{~cm}$. which was statistically at par with $45 \mathrm{~cm}$ row spacing and significantly higher than 22.5 and $30 \mathrm{~cm}$ row spacing. The row spacing of $45 \mathrm{~cm}$ was also recorded significantly higher leaf width of brown top millet in comparison to 22.5 and $30 \mathrm{~cm}$. row spacing. However, Korir (2019) reported that spacing had no significant difference in leaf width.

\section{Leaf length}

The highest leaf length $(18.1 \mathrm{~cm})$ of brown top millet was recorded with $125 \%$ recommended dose of fertilizer which was significantly higher than 75 and $100 \%$ recommended dose of fertilizer. The significantly higher leaf length of brown top millet was also recorded with $100 \%$ recommended dose of fertilizer in comparison to $75 \%$ recommended dose of fertilizer. Similarly, Korir (2019) reported significant 
difference in leaf length due to doses of fertilizer. The highest leaf length $(17.5 \mathrm{~cm})$ of brown top millet was recorded with $60 \mathrm{~cm}$. row spacing which was significantly higher than 45,30 and $22.5 \mathrm{~cm}$. row spacing. It was also found that narrowing the row spacing significantly decreased the leaf length of brown top millet. However, Korir (2019) didn't find any significant difference in leaf length with the differences in the row spacing.

\section{Leaf area index}

The highest leaf area index (1.36) of brown top millet was recorded with $125 \%$ recommended dose of fertilizer which was significantly higher than 75 and $100 \%$ recommended dose of fertilizer. The significantly higher leaf area index of brown top millet was also recorded with $100 \%$ recommended dose of fertilizer in comparison to $75 \%$ recommended dose of fertilizer.

The highest leaf area index (1.49) of brown top millet was recorded with $60 \mathrm{~cm}$. row spacing which was significantly higher than 45,30 and $22.5 \mathrm{~cm}$. row spacing. It was also found that narrowing the row spacing significantly increased the leaf area index of brown top millet.

It was found that narrowing the row spacing from 60 to 45,45 to 30 and 30 to $22.5 \mathrm{~cm}$ significantly increased the leaf area index of brown top millet under 100 and $125 \%$ recommended dose of fertilizers, however, under $75 \%$ recommended dose of fertilizers, the leaf area index of brown top millet increased significantly with narrowing the row spacing from 45 to $30 \mathrm{~cm}$ and row spacing $45 \mathrm{~cm}$ is at par with $60 \mathrm{~cm}$ and $30 \mathrm{~cm}$ is at par with $22.5 \mathrm{~cm}$.

It could be concluded from these results that the leaf area index of brown top millet responded significantly to higher doses of fertilizer i.e. 100 and $125 \%$ of RDF at each level of row spacing. The leaf area index of brown top millet didn't respond to lower level of fertilizer i.e. $75 \%$ of RDF under wider row spacing i.e. $60 \mathrm{~cm}$.

The leaf area index increased significantly with increasing the level of fertilizer from 75 to 100 and 100 to $125 \%$ of recommended dose under 22.5 and $30 \mathrm{~cm}$ row spacing of brown top millet, however, the leaf area index under $45 \mathrm{~cm}$ row spacing of brown top millet was increased significantly when level of fertilizer increased from 75 to $100 \%$ of RDF only and under $60 \mathrm{~cm}$ row spacing, from 100 to $125 \%$ of RDF only. Increasing fertilizer level from 100 to $125 \%$ of RDF under $45 \mathrm{~cm}$ row spacing and from 75 to $100 \%$ of RDF under $60 \mathrm{~cm}$ row spacing didn't produce any significant effect on the leaf area index of brown top millet.

It could be concluded from these results that narrowing the row spacing of brown top millet from 45 to 30 or $22.5 \mathrm{~cm}$, responded significantly to each and all the levels of fertilizer under study.

\section{Number of grains finger ${ }^{-1}$}

The result showed that the highest number of grains (519) per finger of brown top millet is found with the treatment $125 \%$ recommended dose of fertilizer which was significantly higher than 75 and $100 \%$ recommended dose of fertilizer. Similar findings were reported by Ojha et al., (2018).

The highest number of grains (485) per finger of brown top millet was found with the row spacing of $60 \mathrm{~cm}$ which was significantly higher than 45, 30 and $22.5 \mathrm{~cm}$ row spacing. Narrowing the row spacing of brown top millet from 60 to 45,45 to 30 and 30 to 22.5 $\mathrm{cm}$. significantly decreased the number of grains per finger. Ashraf et al., (2015) was also reported similarly. 


\section{Biological yield}

The results reveal that the treatment with $125 \%$ of recommended doses of fertilizer recorded significantly higher biological yield (53.3 $\mathrm{q} \mathrm{ha}^{-1}$ ) of brown top millet as compared to $75 \%$ of recommended doses of fertilizer and statistically at par with the treatment $100 \%$ of recommended doses of fertilizer. Jat et al., (2002) also reported similarly.

The results reveal that the treatment with the spacing of $22.5 \mathrm{~cm}$ recorded significantly higher (68.3 $\left.\mathrm{q} \mathrm{ha}^{-1}\right)$ biological yield of brown top millet than 30,45 and $60 \mathrm{~cm}$ row spacing. Narrowing the row spacing from 60 to 45,45 to 30 and 30 to $22.5 \mathrm{~cm}$. significantly increased the biological yield of brown top millet. Similarly, an increase in biological yield due to narrowing the row spacing was also reported by Ashraf et al., (2015).

\section{Grain yield}

The highest grain yield $\left(6.4 \mathrm{q} \mathrm{ha}^{-1}\right)$ of brown top millet was recorded with $125 \%$ of recommended dose of fertilizer which was significantly higher than 75 and $100 \%$ of recommended dose of fertilizer. Significant increase in grain yield was recorded with each successive level of fertilizer. Bhagchand and Gautam (2000) also reported similarly.

The highest grain yield $\left(7.4 \mathrm{q} \mathrm{ha}^{-1}\right)$ of brown top millet was recorded with $22.5 \mathrm{~cm}$ row spacing which was significantly higher than 30,45 and $60 \mathrm{~cm}$. row spacing. The grain yield of brown top millet was increased significantly with narrowing the level of row spacing. Similar findings were also reported by Giana (2014).

Table.1 Initial soil properties and nutrient status of experimental soil

\begin{tabular}{|c|c|c|c|}
\hline Soil properties & $\begin{array}{l}\text { Initial } \\
\text { status }\end{array}$ & Rating & Method \\
\hline pH & 5.86 & Slightly acidic & $\mathrm{pH}$ meter \\
\hline $\mathrm{EC}\left(\mathrm{dS} \mathrm{m}^{-1}\right)$ & 0.10 & Normal & EC meter \\
\hline OC $(\%)$ & 0.55 & Medium & Walkley and Black (1939) \\
\hline$N\left(k_{g ~ h a}{ }^{-1}\right)$ & 163.07 & Very low & Subbiah and Asija, 1956. \\
\hline $\mathbf{P}\left(\mathrm{kg} \mathrm{ha}^{-1}\right)$ & 10.75 & Medium & Olsen et al., (1954) and Watnabe and Olsen (1965) \\
\hline$K\left(\mathrm{~kg} \mathrm{ha}^{-1}\right)$ & 204 & Medium & Muhr et al., (1965) using flame photometer \\
\hline $\operatorname{Mn}\left(\mathrm{mg} \mathrm{kg}^{-1}\right)$ & 24.21 & Sufficient & Lindsay and Norvell (1978) using AAS \\
\hline $\mathrm{Fe}\left(\mathrm{mg} \mathrm{kg}^{-1}\right)$ & 11.15 & Sufficient & Lindsay and Norvell (1978) using AAS \\
\hline $\mathrm{Zn}\left(\mathrm{mg} \mathrm{kg}^{-1}\right)$ & 1.2 & Sufficient & Lindsay and Norvell (1978) using AAS \\
\hline $\mathrm{Cu}\left(\mathrm{mg} \mathrm{kg}^{-1}\right)$ & 1.58 & Sufficient & Lindsay and Norvell (1978) using AAS \\
\hline
\end{tabular}


Table.2 Effect of levels of fertilizer on yield and growth parameters of brown top millet in Entisols of Bastar plateau

\begin{tabular}{|c|c|c|c|c|c|c|c|c|c|c|}
\hline \multirow{2}{*}{$\begin{array}{l}\text { S. } \\
\text { No. }\end{array}$} & \multirow{2}{*}{$\begin{array}{l}\text { Yield and growth parameters of } \\
\text { brown top millet }\end{array}$} & \multicolumn{3}{|c|}{ Fertilizer levels (\% of RDF) } & \multirow{2}{*}{$\begin{array}{c}\text { CD } \\
(\mathbf{P}=\mathbf{0 . 0 5})\end{array}$} & \multicolumn{4}{|c|}{ Row spacing (cm) } & \multirow{2}{*}{$\begin{array}{c}\mathrm{CD} \\
(\mathrm{P}=\mathbf{0 . 0 5})\end{array}$} \\
\hline & & 75 & 100 & 125 & & 22.5 & 30 & 45 & 60 & \\
\hline 1. & Plant height $(\mathrm{cm})$ & $99.1^{\mathrm{a}}$ & $100.3^{\mathrm{a}}$ & $103.3^{\mathrm{b}}$ & 1.7 & 106.9 & 102.4 & 98.2 & 96 & 3.5 \\
\hline 2. & Number of tillers plant ${ }^{-1}$ & $5.0^{\mathrm{a}}$ & $5.2^{\mathrm{ab}}$ & $5.4^{\mathrm{b}}$ & 0.26 & 4.3 & 5.0 & 5.4 & 6.0 & 0.20 \\
\hline 3. & Number of secondary tillers plant ${ }^{-1}$ & $4.1^{\mathrm{a}}$ & $4.6^{\mathrm{a}}$ & $5.3^{\mathrm{a}}$ & NS & 3.1 & 3.7 & 4.9 & 7.0 & 0.99 \\
\hline 4. & Number of fingers plant ${ }^{-1}$ & $8.8^{\mathrm{a}}$ & $9.3^{\mathrm{b}}$ & $9.9^{c}$ & 0.42 & 7.5 & 8.8 & 9.8 & 11.2 & 0.56 \\
\hline 5. & Finger length $(\mathrm{cm})$ & $14.0^{\mathrm{a}}$ & $15.0^{\mathrm{b}}$ & $16.3^{\mathrm{c}}$ & 0.50 & 14.5 & 14.9 & 15.2 & 15.9 & 0.24 \\
\hline 6. & Number of leaves plant ${ }^{-1}$ & $10.5^{\mathrm{a}}$ & $11.1^{b}$ & $11.5^{\mathrm{c}}$ & 0.34 & 10.6 & 10.9 & 11.1 & 11.4 & 0.21 \\
\hline 7. & Leaf width $(\mathrm{cm})$ & $2.0^{\mathrm{a}}$ & $2.2^{\mathrm{ab}}$ & $2.3^{\mathrm{b}}$ & 0.21 & 2.1 & 2.1 & 2.2 & 2.2 & 0.05 \\
\hline 8. & Leaf length $(\mathrm{cm})$ & $14.4^{\mathrm{a}}$ & $16.3^{b}$ & $18.1^{\mathrm{c}}$ & 0.70 & 15.1 & 16.0 & 16.6 & 17.5 & 0.40 \\
\hline 9. & Leaf area index & $0.82^{\mathrm{a}}$ & $1.10^{b}$ & $1.36^{\mathrm{c}}$ & 0.16 & 1.49 & 1.25 & 0.90 & 0.75 & 0.06 \\
\hline 10. & Number of grains finger ${ }^{-1}$ & $350^{\mathrm{a}}$ & $419^{b}$ & $519^{c}$ & 56.0 & 367 & 418 & 447 & 485 & 25.0 \\
\hline 11. & Biological yield $\left(\mathrm{q} \mathrm{ha}^{-1}\right)$ & $47.8^{\mathrm{a}}$ & $51.4^{b}$ & $53.3^{c}$ & 0.98 & 68.3 & 53.8 & 43.9 & 37.4 & 5.16 \\
\hline 12. & Grain yield $\left(\mathrm{q} \mathrm{ha}^{-1}\right)$ & $5.4^{\mathrm{a}}$ & $5.8^{\mathrm{b}}$ & $6.4^{c}$ & 0.15 & 7.4 & 6.3 & 5.2 & 4.7 & 0.39 \\
\hline 13. & Straw yield $\left(\mathrm{q} \mathrm{ha}^{-1}\right)$ & $42.4^{\mathrm{a}}$ & $45.6^{b}$ & $46.9^{c}$ & 1.01 & 60.9 & 47.5 & 38.7 & 32.7 & 5.19 \\
\hline 14. & Harvest index $(\%)$ & $11.5^{\mathrm{a}}$ & $11.5^{\mathrm{a}}$ & $12.2^{\mathrm{b}}$ & 0.18 & 10.8 & 11.7 & 11.8 & 12.7 & NS \\
\hline 15. & Test weight (g 1000 ${ }^{-1}$ grains) & $2.5^{\mathrm{a}}$ & $2.9^{\mathrm{b}}$ & $3.0^{\mathrm{b}}$ & 0.11 & 2.7 & 2.8 & 2.9 & 2.9 & NS \\
\hline
\end{tabular}

$\mathrm{CD}=$ Critical difference, $\mathrm{P}=$ Probability level of significance, NS=Not significant, RDF=Recommended dose of fertilizer, $\mathrm{cm}=\mathrm{centimeter}$, Same small letters superscripted to data are at par as per Duncan's multiple range test. 

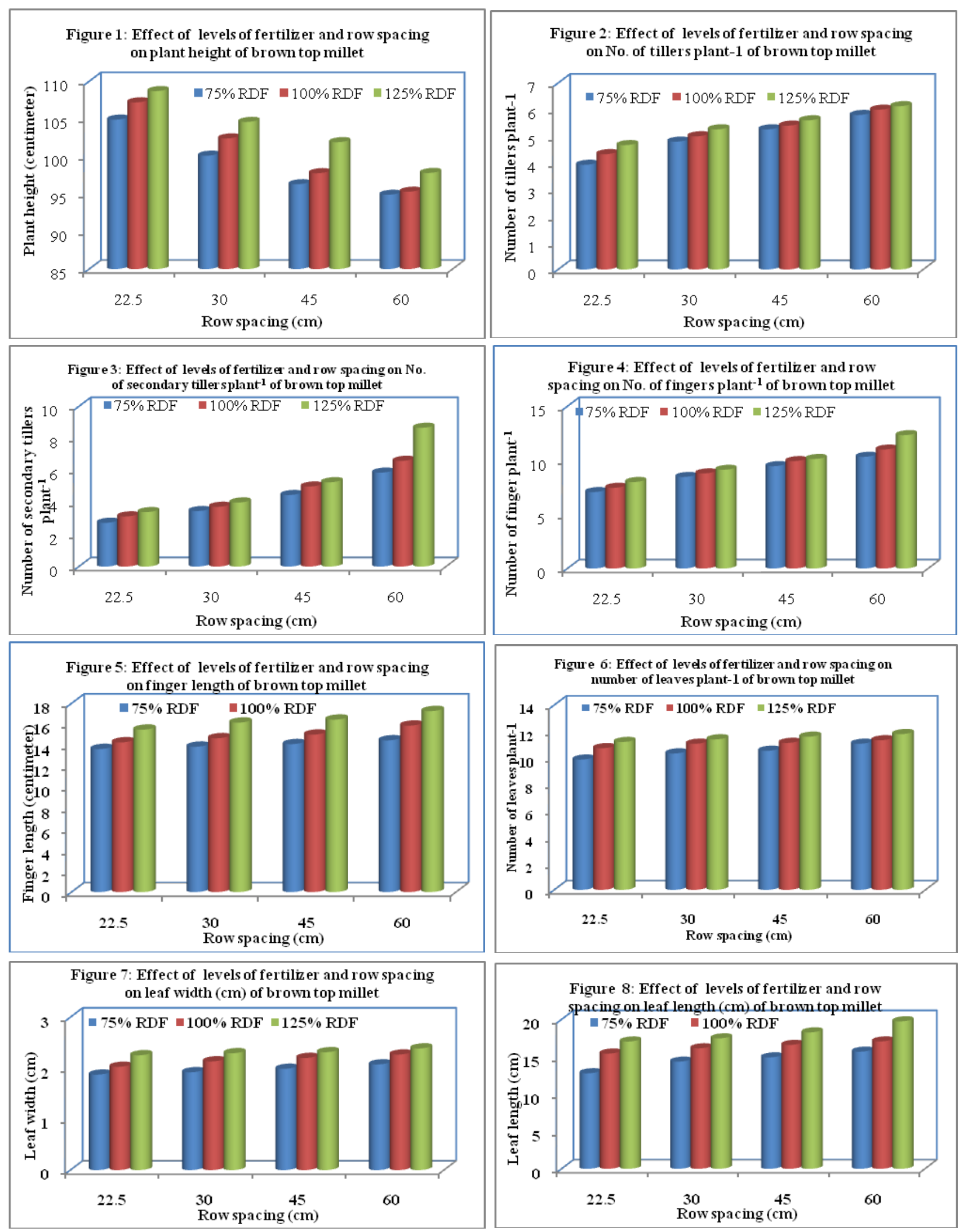

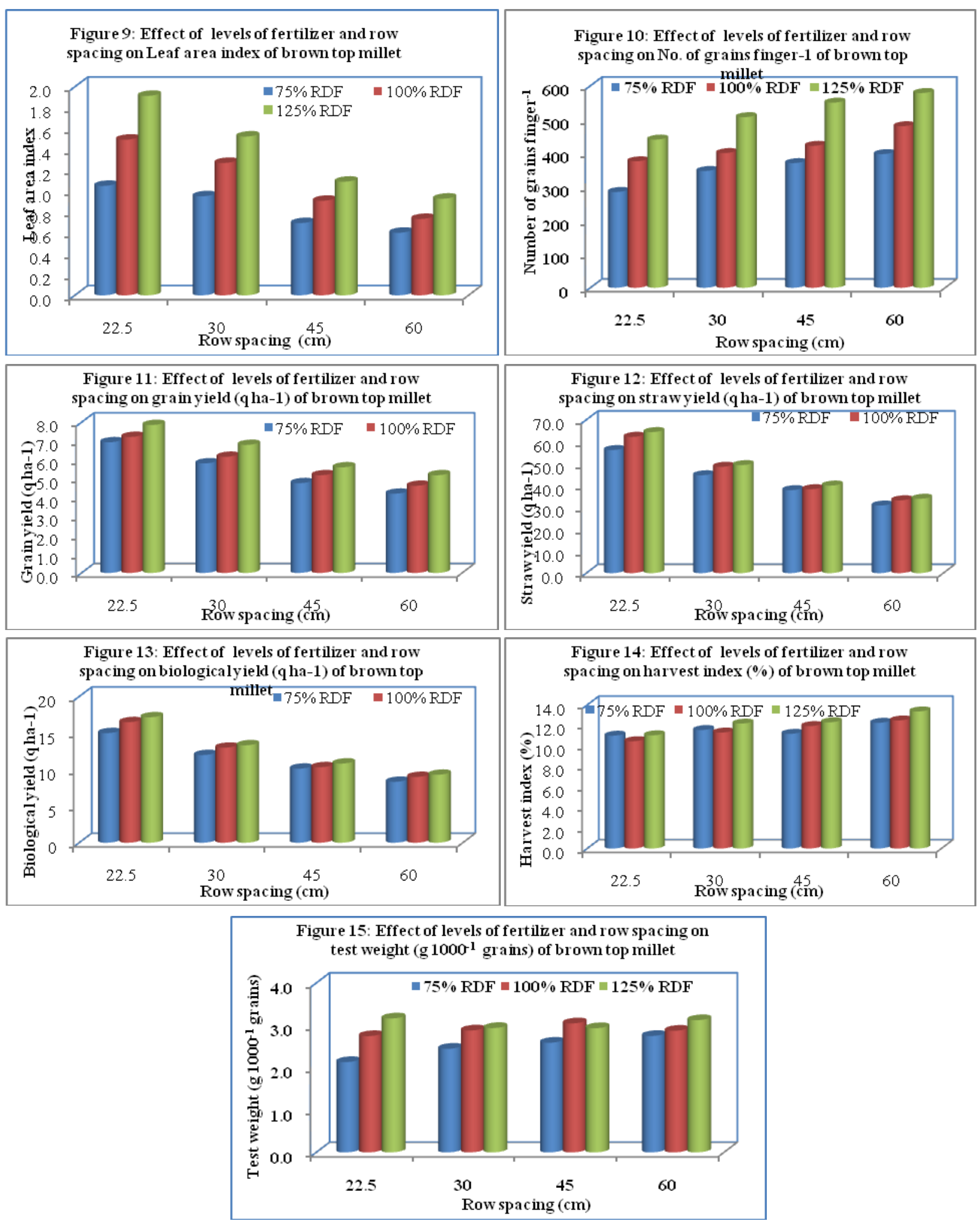


\section{Straw yield}

The results reveal that the treatment with $125 \%$ of recommended doses of fertilizer recorded significantly higher straw yield (46.9 $\mathrm{q} \mathrm{ha}^{-1}$ ) of brown top millet as compared to $75 \%$ of recommended doses of fertilizer and statistically at par with the treatment $100 \%$ of recommended doses of fertilizer. Thakur et al., (2019) also reported similarly.

The results reveal that the treatment with the spacing of $22.5 \mathrm{~cm}$ recorded significantly higher $\left(60.9 \mathrm{q} \mathrm{ha}^{-1}\right)$ straw yield of brown top millet than 30, 45 and $60 \mathrm{~cm}$ row spacing. Narrowing the row spacing from 60 to 45, 45 to 30 and 30 to $22.5 \mathrm{~cm}$. significantly increased the biological yield of brown top millet. Similarly, an increase in fodder yield due decrease of the row spacing was also reported by Thakur et al., (2019).

\section{Harvest index}

The harvest index (12.2\%) of brown top millet was found significantly higher with $125 \%$ recommended dose of fertilizers as compared to $100 \%$ and $75 \%$ recommended dose of fertilizers. The result obtained was in accordance with Aghdam et al., (2014) where they found that the treatment had a significant effect on harvest index. In their experiment the highest harvest index $150 \mathrm{~kg} \cdot \mathrm{ha}^{-1}$ was obtained from of urea as compared to nonurea fertilizer treatments. Similarly, Ojha et al., (2018) reported the higher harvest index with the treatment $60: 60: 20 \mathrm{~kg} \mathrm{ha}^{-1}$ of NPK.

The harvest index of brown top millet was not influenced significantly with the levels of row spacing.

\section{Test weight}

The test weight of brown top millet was recorded statistically at par with 100 and
$125 \%$ of recommended dose of fertilizes but both the doses produced significantly higher test weight of brown top millet as compared to $75 \%$ of recommended dose of fertilizes. Mukhtar et al., (2011) also observed similarly that application of nitrogen and phosphorus at the rate of $250 \mathrm{~kg} \mathrm{~N}+125 \mathrm{~kg} \mathrm{P}_{2} \mathrm{O}_{5} \mathrm{ha}^{-1}$ to maize gave maximum 1000-grain weight. Tripati and Kushwaha (2013) also reported similarly in case of pearl millet. Row spacing had no influence on test weight of brown top millet.

\section{References}

Aghdam, S.M., Yeganehpoor, F., Kahrariyan, B., Shabani, E. 2014. Effect of different urea levels on yield and yield components of Corn 704. International Journal of Advanced Biological and Biomedical Research. 2(2): 300-305

Amjad, M. and Anderson, W. 2006. Managing yield reduction from wide spacing in wheat. Australian Journal of Experimental Agriculture. 46(10):1313

Ashraf, U., Anjum, S.A., Ehsanullah and Khan, I. 2014. Planting geometryinduced alteration in weed infestation, growth and yield of puddled rice. Pak. J. Weed Sci. Res.20 (1): 77-89.

Chamroy T., Kale, V.S., Nagre, P.K., Dod, V.N., Wanjari, S.S. and Jahagirdar, S, W. 2017. Growth and Yield Response of Baby Corn (Zea Mays L.) to Sowing Time and Crop Geometry. Chem Sci Rev Lett. 6(22): 978-981.

Choudhari, A.C., Meena, N.L. and Jat, R.L. 2002. Effect of nitrogen and moisture conservation practices on growth and yield of rainfed pearlmillet [Pennisetum glaucum (L.) R. Br.]. Annals of Agricultural Research.123 (2): 223-225.

Dona,S., Rajasree G., and Sudha B. 2016. Effect of varieties and spacing on growth, yield and economics of cultivation of baby corn (Zea mays L.) 
as intercrop in coconut garden. Research on Crops. 673-678.

Dereje G., Bogale T., Raghavaiah, C.V., Walelegn, B., and Chavhan, A.B., 2016. On- farm productivity response of rainfed grain Sorghum (Sorghum bicolor L.) to integrated nutrient supply system in Assosa Zone, Western Ethiopia, East Africa. Int. J. of Life Sciences. Vol. 4 (2): 169-175.

Giana, G.K. 2014. Effect of intercropping and fertility levels on growth, yield and quality of pearl millet (Pennisetum glaucum (L.) R.Br. emend Stuntz]. M.Sc. Thesis. Submitted to Sri Karan Narendra Agriculture University, Jobner, Jaipur (Rajasthan) India.

Hulihalli U. K., and Shantveerayya, 2018, Evaluation of buckwheat genotypes to different planting geometries and fertility levels in northern transition zone of Karnataka, World Academy of Science, Engineering and Technology International Journal of Agricultural and Biosystems Engineering.12(2): 6468.

Jat, R. L., Sharma, O. P. and Chaudhari, A. C. 2002. Effect of nitrogen and sulphur on yield and quality of pearlmillet (Pennisetum glaucum). Annals of Agricultural Research. 23 (2): 226-228.

Korir, A.K., 2019. The effects of fertilization and spacing on growth and grain yields of finger millet (Eeleusine coracana 1.) in ainamoi, kericho county, Thesis. Submitted to the school of science and technology, Kenya Methodist University.

Kumari, C. R., Shanthi, P., Niveditha, M., Sudheer, K. V. S., Reddy, B. S. 2015. Growth and yield of bajra hybrid as influenced by spacing and nitrogen levels in rainfed alfisols. Andhra Pradesh J. Agril. Sci. 2(2): 96-103

Mahato, M. and Adhikari, B.B. 2017. Effect of planting geometry on growth of rice varieties, Int. J. Appl. Sci. Biotechnol. 5(4): 423-429.

Mukhtar, T., Muhammad, A., Shahid, H., Muhammad, T. and Khalid, M. 2011. Effect of different rates of nitrogen and phosphorus fertilizers on growth and yield of maize. Journal of Agricultural Research. 49 (3): 442-450.

Nigade, R.D., and More, S.M. 2013. Performance of finger millet varieties to different levels of fertilizer on yield and soil properties in sub-montane zone of Maharashtra. Int.J. Agri. Sci. 9(1): 256259.

Obeng, E., Cebert, E., Singh, B.P., Ward, R., Nyochembeng, L.M. and Mays, D.A. 2012. Growth and Grain Yield of Pearl Millet (Pennisetum glaucum) Genotypes at Different Levels of Nitrogen Fertilization in the Southeastern United States, Journal of Agricultural Science. 4 (12):155-163.

Ojha, E., Adhikari, B., and Katuwal, Y. (2018). Nurient Management Trial on Foxtail Millet at Sundarbazar, Lamjung. Journal of the Institute of Agriculture and Animal Science. 35(1): 89-94.

Pandey, S.K., Kaushik, S. K. and Gautam, R.C. 1988. Response of rainfed pearl millet to plant density and moisture conservation, Indian J. Agro. 58 (7): 517-520

Prakasha, G., Murthy, K.N.K., Prathima, A.S. and Rohani, N.M. 2018. Effect of Spacing and Nutrient Levels on Growth Attributes and Yield of Finger Millet (Eleusine coracana L. Gaertn) Cultivated under Guni Planting Method in Red Sandy Loamy Soil of Karnataka, India. Int.J.Curr.Microbiol.App.Sci. 7(5): 1337-1343.

Prakash, C. and Singh, J.P. 2014. Effect of fertility levels and spacing on growth, yield and quality of pearl millet (Pennisetum glaucum) hybrids under 
dryland condition. Environment and Ecology, 32 (2A): 702-704.

Sonboir, H.L., Kumar, M., Kumar, B., and Sahu, B.K. 2017.Effect of planting geometry and nutrient levels on yield and Zinc concentration in grains of High Zinc Rice (Oryza sativa L.). International journal of current microbiology and applied sciences, 6(9): 2027-2033

Thakur, A, K., Kumar, P. and Netam, P. S. 2019. The effect of different nitrogen levels and plant geometry, in relation to growth characters and yield of browntop millet (Brachiaria ramosa L.) at Bastar Plateau Zone of Chhattisghar.
Int.J.Curr.Microbiol.App.Sci. $\quad$ 8(2): 2789-2794.

Tripathi, A .K. and Kushwaha H.S. 2013. Performance of pearlmillet (Pennisetum glaucum) intercropped with pigeonpea (Cajanus cajan) under varying fertility levels in the rainfed environment of Bundelkhand region. Annals of Agricultural Research. 34 (1): 36-43.

Yadav, R.S. and Jangir R.P. 1997. Spatial arrangement of pearl millet (Pennisetum glaucum) under different plant densities in arid zone of Rajasthan. Indian J. Sci. 67: 318-319.

\section{How to cite this article:}

Danish Ahmed Siddiqui, G.K. Sharma, T. Chandrakar, A.K. Thakur and Pradhan, A. 2020. Differential Levels of Fertilizer and Row Spacing Affects Growth and Yield of Brown Top Millet [Brachiaria ramosa (L.)] in Entisols of Bastar Plateau Zone of Chhattisgarh. Int.J.Curr.Microbiol.App.Sci. 9(08): 3459-3472. doi: https://doi.org/10.20546/ijcmas.2020.908.401 